\title{
Supervision of Principals and Teacher Work Discipline on the Primary School Teacher Performance
}

\author{
Suharti Munawaroh Handayani ${ }^{*}$ ) Happy Fitria $^{2}$, Yessi Fitriani ${ }^{2}$ \\ ${ }^{1}$ SD Negeri 143 OKU \\ ${ }^{2}$ University of PGRI Palembang \\ *Corresponding author. Email: suhartimh@gmail.com
}

\begin{abstract}
The objective of this study is to analyze the effect of principal's supervision on the performance of public elementary school teachers; the effect of teacher work discipline in the performance of elementary school teachers; and the effect of principal supervision and teacher discipline in the performance of elementary school teachers. This research uses quantitative methods. This research was conducted in Lubuk Raja District with a sample of 118 teachers. Data collection techniques are questionnaires and documentation. The data were analyzed using the SPSS For Windows Version 21 program. The results showed that (1) there was a positive relationship between the supervision of the principal on the performance of public elementary school teachers in Lubuk Raja District; (2) there is a strong influence between teacher work discipline in the performance of public SD teachers in Lubuk Raja District; and (3) the guidance and job discipline of the principal have a direct influence on the students' success. of public elementary school teachers in Lubuk Raja District.
\end{abstract}

Keywords: Principal Supervision, Teacher Work Discipline, Teacher Performance

\section{INTRODUCTION}

A school is a hierarchical educational organization that organizes the teaching and learning process in order to meet educational objectives. The level of quality of education is much influenced by the quality of the learning process performed by the teacher because the teacher directly provides guidance and assistance to students in an effort to achieve educational purpose. Therefore, a good teacher performance is needed. This opinion explains that the leadership of principal's greatly affects on the teachers' performance. The teacher's performance can increase and help to raise the standard of education in schools. The above opinion is also supported by the research conducted by Arafat [1] in the journal Education Management, with the title "The Effect of Academic Supervision and Teacher Professional Competence on Teacher Performance in Public High Schools in Tanjung Raja District."

Arafat's research shows that there is a significant impact of academic supervision on the teachers' performance at the State Senior High School in the Tanjung Raja District. This research also shows the results which state that after supervision of the principal of the school teacher is carried out, the results will improve teacher performance.

With the increase in teacher performance, the quality of education will also increase. Teacher performance is the factor that determines the quality of learning most, the participation of teachers in relation to the quality of education can at least be seen from four dimensions, namely the teacher as an individual, the teacher as an element of the family, the teacher as an element of education, and teachers as elements of society. The performance of the teacher's role in relation to the quality of education must start by itself. As a person, a teacher is a self-manifestation with all the unique characteristics that are in accordance with his position as a teacher of the teaching profession [2].

The principal plays a critical position in enhancing teacher success by encouraging them to be more enthusiastic and knowledgeable in the classroom. This shows that teachers are expected to be able to play an active role as managers of the teaching and learning process acting as facilitators who always try to create class organizations, use teaching methods and teacher attitudes and characteristics in managing the teaching and learning process [3]. School apparatus such as 
principals, teacher councils, students, employees / employees must support each other to work together to achieve predetermined goals.

Therefore, it can be said that the success or failure of an educational institution in achieving predetermined goals is very much dependent on the ability of the leaders to foster a climate of cooperation so that it can easily mobilize existing human resources. The utilization can run effectively and efficiently. One of the main keys to the success of education lies in the quality of teachers. Teachers have the main task, namely: making learning programs, implementing learning programs, conducting evaluations, analyzing student learning outcomes, implementing improvements, remedies, and enrichment [4].

There is a strong tendency that in order to raise the standard of service in teacher professional qualifications that need to be nurtured and reorganized is its ability so that in turn, it can be used to direct teacher programs to become professional figures in education. This is inseparable from the assistance and guidance of the supervisor.

In carrying out their duties, a supervisor is obliged to help the teacher to provide support who can carry out their duties both as an educator and as a teacher. As professional teachers, they must have special skills and be able to master the intricacies of education and teaching with a variety of sciences that need to be nurtured and developed through certain educational periods. Thus, it means that teachers need supervision. With supervision, the principal as a superior can find out the mistakes or shortcomings in the teacher's performance of his duties, then coaching or finding solutions to solving the problems faced by the teacher can be done, so that the teaching and learning process in schools is not disturbed. Supervision helps teachers to identify management issues.

Suprihatiningrum [5] states that as long as identifying a problem is a continuous challenge for the leadership, this contribution of supervision is very relevant. Supervision and work discipline are elements of management. Continuous supervision activities are needed to help smooth tasks. Through supervision, teachers can get guidance and supervision necessary for administrative purposes for the teacher himself. Teacher performance increases and is able to excel and be able to catch up, compete with other schools. Therefore, teachers who teach must be really disciplined.

Based on the description above, there is one main problem, namely, whether there is an effect of principal supervision and teacher work discipline in the performance of elementary school teachers. Researchers are involved in undertaking research with the title in this respect "Supervision of Principals and Teacher Work Discipline on Primary School Teacher Performance"
Performance is the result obtained based on a certain task/function in a certain period. Performance may be viewed as a function of a number of variables of the teacher efforts that is achieved with abilities and actions in certain situations [6]. Meanwhile, according to Mathis and Jacson [7] who states that performance is what is done and not done. Their commitment to the institution is influenced by their success, which includes the output of (1) quantity, (2) quality, (3) duration, (4) attendance at work, (5) cooperative attitude. The above opinion shows that in order to improve their performance, teachers must strive in various ways, including the quality of teaching and their teaching discipline.

According to Supardi [8], the skill and effectiveness of a teacher in carrying out learning assignments is referred to as teacher efficiency according to the authority and responsibility given by the school, in an effort to achieve the vision, mission and goals of the school. According to Purbasari [9], teacher performance can be seen from their success in implementing learning in schools to achieve the school's vision and mission. Therefore, all parties should be able to motivate teachers in teaching, so that teacher performance can be improved. This task is not only the principal's, but all school members.

The term supervision in educational institutions is often referred to as supervision. According to Nasifah [10], the purpose of supervision is to provide technical assistance and guidance to teachers in improving their quality. Etymologically, supervision comes from the words "super" and "vision" that involves seeing and reviewing from a higher viewpoint or seeing and assessing from a higher perspective. This task was carried out by the superior in relation to Mulyasa's subordinates' behavior, ingenuity, and efficiency [11]. Meanwhile Hartanto [12] explains that supervision is a management function, management is the process of planning, organizing, mobilizing, and supervising activities, according to the organization in order to achieve a coordination of resources. Human and natural resources, in terms of achieving goals effectively and efficiently. According to Sudiyono [13] the competence of academic supervision aims to foster teachers in improving the quality of the learning process.

Supervision is a process of guidance from the principal to teachers and school personnel who directly handle student learning, besides that, it also improves work and learning situations in an effective, disciplined, responsible manner and fulfills the accountability [5]. The key word for the implementation of supervision is "to provide services and assistance". A similar viewpoint was also shared by Happy [14] saying that supervision is almost the same as supervision, but supervision is more about coaching. Supervision is needed in educational institutions because one of the 
competences of the Principal is Supervision. According to Bernawi and Fauziah [15], the initiative of school duties in guiding teachers and other officers in strengthening education is referred to as supervision. According to Rismawan [16] school principal supervision is a form of guidance, assistance and supervision services. Furthermore, supervision should be a curriculum established by schools and supportive agencies, as well as the provision of instruction, and assisted by teacher-led programs. In order to meet school outcomes, educators use supervision to increase the efficiency and number of team members required to address issues.

Supervision should be carried out through several steps, continuous, continuous, and the supervisor without getting bored. To fulfill this task, the principal is not allowed to work only for the glory of the school at present, or more extreme when he leads the school. The principal must not work just to make a name for himself. By fostering teachers to be diligent and on time, so that the wheels of the school organization journey run smoothly without thinking about the teacher's future. Meanwhile Kristiawan [17] stated that supervision is the view of people who are more skilled with people who have lower expertise. According to Suroso [18], the purpose of supervision is to help teachers learn how to increase their capacity to achieve learning goals.

Based on some of the expert opinions above, as a consequence, supervision should be thought of as a combination of coaching and specialist activities. This is to support teachers and other education staff in developing instructional tools, processes, and assessment by constantly inspiring, organizing, and directing teachers so that they become more professional in achieving school goals.

Daryanto [19] writes that to achieve the goal of educational supervision, follow-up supervision requires guidance or advice from supervisors to teachers and employees and school officers to improve the quality of results in the learning process and try to remove obstacles that have been evaluated previously.

Meanwhile, Hartanto [20] states that the purpose of academic supervision in education is to develop better teaching and learning situations through coaching and enhancing the teaching profession. So the keyword for supervision as described above is to provide assistance and services to teachers. Supervision is carried out to develop learning and teaching situations carried out by teachers in class and outside the classroom. In addition, Afriansyah [21] explains that the overall goal of supervision is to provide professional support and advice to teachers and staff so that they can increase the consistency of their work and the teaching and learning process. According to Subandi [22] the principal is in charge of classroom supervision having an influence on teacher performance, especially in the learning activities carried out.

Based on the above opinion, it can be concluded that the main purpose of educational supervision is to determine the situation and condition of a learning process in schools. So that errors can be detected and corrected through a process of evaluation and direction by supervisors to teachers and school officers. Finally, a school with a better and better quality teaching and learning process was realized.

Discipline refers to a person's knowledge of and ability to observe both business rules and social standards. The attitude of a person who voluntarily obeys all rules and is aware of his duties and responsibilities is defined as awareness. According to Rivai in Ningsih [23] work discipline is a communication technique used by supervisors to encourage workers to modify their actions in order to boost consciousness and a person's ability to obey existing social standards. According to Fortuna and Mahirah Work discipline is the obedience or obedience of employees to obey the existing regulations in an institution, both written and unwritten.

Ratminto and Winarsih [24] stated that a disciplined attitude will greatly help someone complete work on time and in accordance with the required conditions. This means that the discipline can shape teacher obedience. Discipline is a term provided to describe a state of mind, order, on the other hand, is simply a condition of events or events. Voluntary compliance with outside influences is the basic essence of discipline [25]. So, work discipline is an attitude of respecting, appreciating, obeying, and obeying the applicable regulations, both written and unwritten and being able to carry them out and not avoiding accepting the sanctions. Based on the above opinion, As a result, the teacher's job discipline may be inferred as an obedience and obedience of an educator in carrying out all the rules or regulations that have been enforced in school with full awareness from within.

In the standardized Indonesian Dictionary as quoted by Wahjosumidja in Ahmad Susanto, the word "principal" is made up of two words: "head" and "school." The term "head" can refer to an organization's or institution's chairman or leader. In the meantime, a school is a place where students obtain and offer classes. Leadership is a process of one's activities to mobilize others with leaders, guide, influence others, to do something in order to achieve the expected results.

According to Wahjosumidja in Ahmad Susanto, the Principal as a functional teacher who is assigned the task of leading a school, which is organized by a teaching and learning process, or an interaction between teachers and students. Leadership is a manager's activity to inspire, influence workers, both as individuals and as 
a team to understand what to do and how to do it to achieve organizational goals.

Meanwhile, according to Helmawati states that the principal is one of the school personnel who guides and has responsibility with other members to achieve goals. Wijono states that there are 3 tasks and functions of leadership, namely: (1) task functions, including: achieving the goals of group work, defining group tasks, planning work, allocating resources, organizing duties and responsibilities, control quality and check performance, review progress. (2) Team functions, including: maintaining morale and building team spirit, group cohesiveness as a work unit, setting standards and maintaining discipline, group communication systems, training groups, promises from subordinates to leaders. (3) Individual functions, including: maintaining individual needs among group members, solving personal problems, resolving conflicts between group needs and individual needs, and training individuals.

The function of a leader in an organization is to complete tasks to complete the work that is their task and responsibility through other people. The organization has a mission to achieve common goals, so those who are given the task of managing the achievement of organizational goals must optimize and set goals, technical tools / tools and strategies that can be used to achieve organizational goals.

Soetjipto states that to carry out its functions, the principal has the following duties: (1) planning, compiling, guiding, and supervising educational administration activities in accordance with predetermined policies, (2) integrating and coordinating the activities of the units. Work units in the school environment, (3) establish relationships and cooperation with parents, government and non-government agencies and the community, and (4) report the implementation and results of administrative activities at school to their direct superiors.

\section{METHODS}

The research method used by the author in this study is a quantitative research method, namely research that is required to use numbers, starting from data collection, interpretation of the data, and the appearance of the results. The data collection techniques used in this study were questionnaires, observation and documentation.

\section{RESULTS AND DISCUSSION}

Several conclusions can be taken from the study findings subjects in this study, namely (1). There is a significant effect of school principal supervision on the performance of public SD teachers in Lubuk Raja District, Ogan Komering Ulu Regency; (2). There is a significant effect of work discipline in the performance of public elementary school teachers in Lubuk Raja District, Ogan Komering Ulu Regency; (3). There is a significant effect of school principal supervision and work discipline on the performance of public SD teachers in Lubuk Raja District, Ogan Komering Ulu Regency.

Based on the results of the data normality test, it is known that the supervision of the principal for the performance of teachers at SDN in the Lubbock Raja District is normally distributed. Based on the Kolmogrov-Smirnov results, it is known that the significance value of the supervision of the principal is $0.260>0.05$. The results of the distribution of work discipline questionnaires obtained a value of 0.464 . As a result, it can be inferred that school principal oversight and job instruction have a considerable impact on the success of public elementary school teachers in Lubuk Raja District, Ogan Komering Ulu Regency, either partially or concurrently.

According to Mulyadi, the results of their research indicate the effect of principal supervision on teacher performance. This means that the higher the supervision of the principal, the higher the teacher's performance. According to the opinion of Mulyadi et al above, explaining that the supervision of the principal is very necessary in order to improve teacher performance in schools.

Based on the results of linearity, the principal's supervision of teacher performance, the score was 2.743. Partially it shows that $F$ count $>F$ Table of $2.743>0.05$. Thus, it can be concluded that there is a significant impact of the supervision of the principal to the teacher performance. Meanwhile, the results of the linearity of work, discipline on teacher performance are also stated to be linear. The linearity results obtained a value of 67.728 , partially it shows that $F$ count $>F$ Table of 67.728>0.05. Thus, it can be concluded that there is a significant impact of work discipline on teacher performance. The results of the research together also show that the effect of principal supervision and work discipline on teacher performance is stated to be linear. Because the calculated $F$ value> $F$ Table is 34.158> 0.05 . Thus, it can be concluded that there is a significant influence between the supervision of the principal and work discipline on teacher performance.

Based on the findings of the research hypothesis test, the three variables, namely the supervision of the principal (X1) and work discipline (X2) on teacher performance (Y) indicate that (1) There is a substantial influence of principal supervision on the performance of public elementary school teachers in Lubuk Raja District, Ogan Regency. Komering Ulu; (2) there found a significant influence of work discipline in the performance of public elementary school teachers in 
Lubuk Raja District, Ogan Komering Ulu Regency; and (3) there found a significant influence of principal supervision and work discipline on the performance of public elementary school teachers in Lubuk Raja District, Ogan Komering Ulu Regency.

Based on the results of simple linear regression, the $\mathrm{R}$ number is 0.173 . Thus, the supervision of the principal has a less strong influence on teacher performance, this can be proven by the correlation value between 0.200-0.399. While the coefficient of determination $\mathrm{R}$ Squer $\left(\mathrm{R}^{2}\right)$ is 0.030 , which means that the supervision of the principal of SD Negeri in Lubuk Raja District, Ogan Komering Ulu Regency has an effect of $3.0 \%$ and the rest is obtained from other results.

Sometimes the principal in charge of supervision can hinder the operation of the supervision. According to Hamadi's opinion the implementation of academic supervision is carried out by the principal in improving the quality of learning. The inhibiting factor is in addition to the low academic supervision of the principal, which is only assessing and giving teacher errors without giving suggestions and solutions, the principal also has complexity and a heavy duty load. So it is necessary to hold education and train to upgrade the competency of principals. Meanwhile, according to Niswanto which states that supervisors have taken an educational and persuasive approach such as coaching teachers who have difficulty through discussions, case conferences, questions and answers between supervisors and teachers about the obstacles faced in improving teaching abilities. The obstacles encountered in the implementation of supervision were the distance and area of Pidie, so that it took a long time for supervisors to visit certain schools.

Based on the research results, the regression equation is why $=80.663+0.175 \times 1$. This means that if the principal's supervision increases by one point, the teacher's performance will increase by 0.175 . While the $\mathrm{t}$ count obtained a value of 1.656. This means that $\mathrm{t}$ count $>t$ Table or 1.656>0.333, and the significant level is $0.101<0.05$. Thus the supervision of the principal has an influence on the performance of public elementary school teachers in Lubuk Raja District, Ogan Komering Ulu Regency.

Based on the results of simple linear regression of work, discipline, the $\mathrm{R}$ number is 0.657 . Thus, work, discipline has a strong influence on teacher performance. This can be proven by the correlation value between $0.600-0.799$. While the coefficient of determination $\mathrm{R}$ Squer $\left(\mathrm{R}^{2}\right)$ is 0.432 . This means that the discipline of SD Negeri in Lubuk Raja Subdistrict, Ogan Komering Ulu Regency has an effect of $43.2 \%$ and the rest is obtained from other results.
Moreover, research on work, discipline, the regression equation is why $=44.844+0.528 \mathrm{X} 1$. This means that if the work discipline reaches 1 point, the teacher's performance will increase by 0.528 . While the $t$ count obtained a value of 1.656. This means that $t$ count $>\mathrm{t}$ Table or $8.230>0.333$, and the significant level is $0.000<0.05$. Thus work discipline has an influence on the performance of SDN teachers in Lubuk Raja District, Ogan Komering Ulu Regency.

Based on the data of the research, the regression equation $y=39.993+0.072 \times 1$ is obtained, meaning that if the supervision of the principal is better, then teacher's performance will be better as well. $\mathrm{T}$ count obtained $0.875>0.333$ value with a significant one $0.384>0.05$. While work, discipline also has an influence on the performance of public elementary school teachers in the Lubbock Raja District, Ogan Komering Ulu Regency. Because the t value is 7.978 0.333 . While the value of the regression coefficient is 0 . $519 \times 2$ with a constant of 39.993. Thus, the regression equation is obtained as $\mathrm{y}=39.993+0.072 \mathrm{x} 1+0.519$ $\mathrm{x} 2$. Based on the research findings with the principal supervision variable is obtained the value of $\mathrm{f}$ count $>\mathrm{f}$ table or equal to $34.158>3.95$ with a significant value of 0.0000 .05 . This means, together the supervision of the principal and work discipline have an effect on the performance of SDN teachers in Lubuk Raja District, Ogan Komering Ulu Regency.

\section{CONCLUSION}

Based on the test results, simple linear regression, the research is collectively obtained, namely a positive relationship; strong influence; significant changes in teacher performance; and produce teachers who have competence; excel and able to catch up with other schools; as well as competing in a healthy manner to improve student achievement in Public Elementary Schools in Lubuk Raja District, Ogan Komering Ulu Regency.

\section{ACKNOWLEDGMENTS}

Thanks to all school principals and elementary school teachers in Lubuk Raja district. Thanks to Education Management study program, PGRI University of Palembang, South Sumatera. 


\section{REFERENCES}

[1] Arafat, Y. (2020). Pengaruh Supervisi Akademik dan Kompetensi Profesional Guru terhadap Kinerja Guru di Sekolah Menengah Atas Negeri di Kecamatan Tanjung Raja. Jurnal Manajemen Pendidikan. 9(1), 104-114.

[2] Nasution, S. (2014). Azas-Azas Kurikulum. Jakarta: Bumi Aksara.

[3] Hartanto, S. (2019). Supervisi dan penilaian Kinerja Guru. Jakarta: Direktorat Jenderal Guru dan Tenaga Kependidikan.

[4] Aqib, Z. (2010). Profesionalisme Guru. Surabaya. Insan Cendekia

[5] Suprihatiningrim, J. (2013). Guru Profesional: Pedoman Kerja, Kualifikasi dan Kompetensi Guru. Yogyakarta: A-zzur Media.

[6] Bernawi., \& Fauziah. (2015). Supervisi kepala sekolah terhadap kompetisi professional guru. Aceh: Universitas Syiah Kuala.

[7] Mudaki. (2015). Implementasi Supervisi Akademik Kepala Sekolah dalam Meningkatkan Profesionalisme Guru. Jurnal Pendidikan Malang.

[8] Supardi. (2014). Kinerja Guru. Depok: PT Rajagrafindo Persaja.

[9] Purbasari, M. (2015). Pengaruh Supervisi Akademik Terhadap Kinerja Guru Dalam Pembelajaran di Sekolah Dasar Daerah Binaan 1 Kecamatan pengadekan Kabupaten Purbalingga. Semarang: Universitas Negeri 1 Semarang.

[10] Nasifah SL. (2015). Peran Supervisi Pendidikan Dalam Meningkatkan Prosionalisme Guru Pendidikan Agama Islam di SMA Negeri Se Salatiga. Salatiga: IAIN Salatiga.

[11] Mulyasa, E. (2012). Menjadi Kepala Sekolah Profesional. Bandung: Remaja Rosda Karya.

[12] Hartanto, S. (2019). Supervisi dan penilaian Kinerja Guru. Jakarta: Direktorat Jenderal Guru dan Tenaga Kependidikan.

[13] Sudiyono. (2012). Metode Penelitian Pendidikan; Kuantitatif, Kualitatif, Kombinasi, $R \& D$ dan Penelitian Pendidikan. Bandung: Alfabeta.

[14] Fitria, H. (2019). Supervisi Pendidikan. Bandung: Alfabeta.

[15] Bernawi., \& Fauziah. (2015). Supervise kepala sekolah terhadap kompetisi professional guru. Aceh:Universitas Syiah Kuala.

[16] Rismawan, E. (2015). Pengaruh supervise Kepala Sekolah dan Motivasi Berprestasi Guru Terhadap
Kinerja Mengajar Guru. Jurnal Administrasi Pendidikan Volume XXII, No 1.

[17] Kristiawan, M., Yuniarsih, Y. Fitria, H., \& Refika, N. (2019). Supervisi Pendidikan. Bandung: Alfabeta.

[18] Suroso, S. (2015). Pengaruh Supervisi Akademik, Pendidikan dan Pelatihan Kompetisi Profesional Terhadap Kinerja Melalui Motivasi Kerja Guru di SMPKota Pekalongan. Semarang: Universitas Negeri Semarang.

[19] Daryanto. (2011). Administrasi dan Manajemen Sekolah. Jakarta: PT Asdi Mahasatya.

[20] Hartanto, S. (2019). Supervisi dan penilaian Kinerja Guru. Jakarta: Direktorat Jenderal Guru dan Tenaga Kependidikan.

[21] Afriansyah, H., \& Dila, S. (2017). Konsep Dasar, Fungsi dan Peranan Supervisi Pendidikan. Jurnal Universitas Negeri Padang.

[22] Subandi, A. (2013). Supervisi Pendidikan Untuk Pengembangan Profesional Guru Berkelanjutan. Pedagogi, Jurnal Ilmiah Ilmu Pendidikan XIII (2): $1-9$.

[23] Ningsih, S. (2017). Pengaruh disiplin, Kompensasi dan Beban Kerja PrestasiKerja Karyawan PT. Mega Finance Cabang Pekanbaru. Journal 4(1)

[24] Ratminto., \& Winarsih, A. S. (2015). Manajemen Pelayanan; Pengembangan Model Konseptual. Penerapan Citizens dan StandarPelayanan Minimal. Yogyakarta: Pustaka Pelajar

[25] Hughes, A. G., \& Hughes, E. H. (2012). Learning \& teaching pengantar psikologi pembelajaran modern. Bandung: Nuansa Asli. 